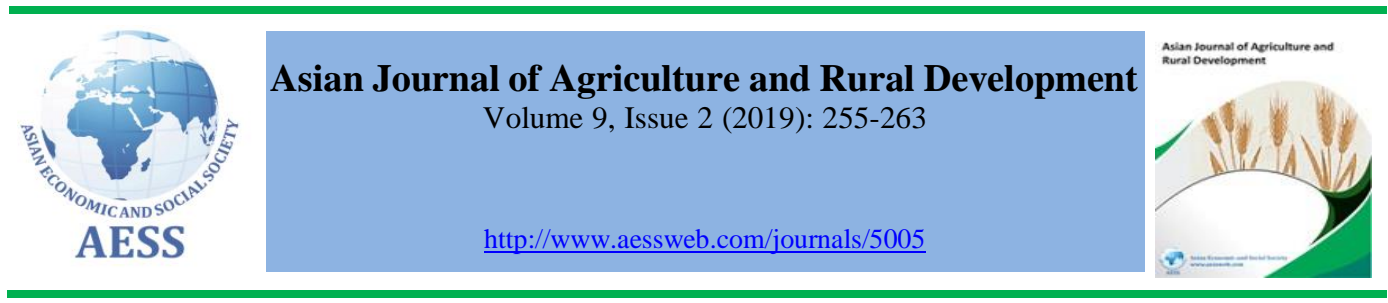

\title{
IS IMPORTED CABBAGE A BETTER CHOICE THAN LOCAL EGG FRUIT FOR SALAD PREPARATION: AN ECONOMIC ANALYSIS OF EKITI STATE, NIGERIA
}

Abiola Matthew
Oladipupo $^{\text {a }}$,

Ibidapo Clement Adedayo $^{\text {a }}$

\section{ARTICLE HISTORY}

Received: 02-Sep-2019

Accepted: 05-Nov-2019

Online Available: 09-Dec-

2019

\section{Keywords: \\ Cabbage, \\ Garden egg salad, \\ Import reduction}

${ }^{a}$ Department of Agricultural Economics Extension, Federal University Oye Ekiti, Ekiti State, Nigeria

matthewabiola201911@yahoo.com (Corresponding author)

\begin{abstract}
The study deals with the possibility of reducing higher ratio of dependence on importation of food through the replacement of foreign products with locally produced and processed food products. In order to accomplish the objectives of the study, both primary and secondary data had been used. Accordingly, a multistage sampling technique was utilized to select the sample size. Descriptive and inferential statistics were eventually applied to the primary data collected. The results indicated undoubtedly that the locally produced and processed salad competed favourably and suitably with foreign salad products in terms of colour, odour, taste, and other sensory parameters evaluated accordingly. The orthodox budget analysis indicated that garden egg salad was more profitable than imported cabbage salad. The correlation outcome value of +1 indicated that local salad stands as a perfect substitute for foreign salad. Therefore, the phasing out of foreign salad so as to replace it with locally sourced salad is quite feasible. It had therefore been obviously and clearly established in this study that imported cabbage could be replaced with locally produced garden egg salad, thereby indicating that reducing the degree of dependence on food importation is absolutely viable.
\end{abstract}

\section{Contribution/ Originality}

This study provides adequate evidence that it is possible to prepare and process vegetable salad from locally produced garden egg fruit as a substitute for salad produced from imported cabbage. Moreover, the outcome shows that locally produced salad competes favourably in terms of taste, nutrients, colour and other parameters examined in the study. Garden egg fruit salad was found to be more profitable in the areas of our study than foreign salad produced from imported cabbage.

DOI: 10.18488/journal.1005/2019.9.2/1005.2.255.263

ISSN (P): 2304-1455/ISSN (E):2224-4433

How to cite: Abiola Matthew Oladipupo and Ibidapo Clement Adedayo (2019). Is imported cabbage a better choice than local egg fruit for salad preparation: an economic analysis of Ekiti state, Nigeria. Asian Journal of Agriculture and Rural Development, 9(2), 255-263. 


\section{INTRODUCTION}

A threefold rising trend is currently found in Nigeria: (i) a rising trend in domestic food demand created out of the population explosion, (ii) a rising trend of shortfall in foods and (iii) a rising trend of food importation therein. The Nigeria Bureau of Statistics (2017) indicated that India, United States, Spain, Netherlands and France were major export partners of Nigeria, accounting for $17.44 \%, 13.92 \%, 9.9 \%, 6.79 \%$ and $6.32 \%$ respectively in third quarter of 2017 . Whereas the major import partners of Nigeria were China, United States, Netherlands, India and United Kingdom importing about $46 \%$ of total import in third quarter of 2017. Nigeria had a positive trade balance of 1.22 billion naira (Nigerian currency) in the third quarter of 2017 but had faced a serious trade deficit in the agricultural and food sectors.

Nigeria experienced a negative trade balance (Lakin, 2018) and its annual food import bills are more than one trillion naira, while the export bills accrued on the nation was about 1.5 billion naira (Audu, 2018). The deficit between food imports and exports seems to be apparently outrageously embarrassing even after using the likely moderately downward adjusted estimations of Audu 2018 statistics of \$22 billion worth of annual food imports, and in accordance with Lakin's (2018) food export value of $\$ 1.5$ billion, gives an obvious deficit of about $\$ 20$ billion. The Nigerian government (2018) reported annual food import value of two billion, seven hundred and seventy-seven million US dollars but surprisingly, Audu (2018) reported the annual food import of $\$ 22$ billion and subsequently repeated the same value in 2017. The value estimated by Audu may have been reviewed with a downward trend simply for political implications. Out of a total export value of $\$ 16.44$ billion from Nigeria, agricultural and food sector accounted for $\$ 0.705$ billion only, representing $4.3 \%$ in the third quarter of 2017 . However, oil exports had always accounted for more than $80 \%$ of total exports from Nigeria. Being the leading crude oil producer, Nigeria imported processed fuel worth about 5 trillion naira in third quarter of 2018. To be more precise, Nigeria is considered to import what it produces with negative implications for loss of revenue, employment ratio, and value addition income.

Out of total trade (representing $\$ 0.705$ billion), undertaken in the Agricultural Sector in Nigeria, the total agricultural export in the third quarter of 2017 was $\$ 0.06$ billion, while the total agricultural import was $\$ 0.65$ billion, besides showing a negative trade balance of $\$ 0.58$ billion within the same period. However, import of agricultural products, such as raw food items and processed foods, are actually estimated to be more than ten times as compared with the local produce. Food supply is therefore considered to be a function of imports, and Nigeria depends heavily on food imports. During the periods of war, any country had to face, by and large, extremely worse and vulnerable situations, especially food shortages. Nigeria experienced such a situation and unwillingly, had to import food worth 43 trillion-naira in six years and also tried to produce some of the food items locally. Wheat, rice, sugar and fish were some of the items which accounted for almost one trillionnaira value for importation in one year.

Nigeria mainly depends on food importation to meet the nutritional demands of the explosive teaming population. There had been a constant trade deficit in agricultural sector of its economy. Food importation had also been embarrassingly higher than food export. All out Government efforts over the years through various plans and programmes failed woefully to secure food security in Nigeria. Plans and programmes like Green Revolution (GR), Operation Feed the Nation (OPFN), Food Accelerated Programmed (FAP), Agricultural Development Programs (ADP), Cassava Initiatives (CI), River Basing Development Authority (RBDA), Agricultural Credit Guaranteed Scheme (ACGS), Bank of Industry (BOI) Peoples Bank (PB) and Cocoa Commodity Board (CCB) among many others proved worthless and baseless Industrial supplies import accounted for $27 \%$, capital goods $23 \%$ and food and beverages for $17 \%$ of total import in 2014 and from then onwards, Nigeria had to depend on food import rather than on domestic food production. For instance, 
Nigeria produced 2 million metric tons of rice annually but imported 3 million metric tons to feed its citizens within some satisfactory limits to some extent. Nigeria imported food worth 1.93billion-naira per annum within a period spanned over 1990-2010 (NBS, 2010; CBN, 2010; Afolami et al., 2012). Food import stood at more than five times the value of food exports (Oboh and Elusiyan, 2004; Oboh et al., 2007; Nwaogu et al., 2007; Ogiehor et al., 2008).

Nigeria has been a nation in troubles frequently due to its aspect of imports. Various vegetables, such as okra fruit, cabbage, cucumber, carrot, tomatoes, etc. are imported to Nigeria via the LagosBenin border. Cameroon and Benin republics are real good and reliable exporters of tomatoes to fulfil the needs between domestic food demand and supply by looking inwards. Is it possible to reduce food importation in Nigeria by sourcing cabbage and carrots for salad preparation? The question is of vital importance and needs to be examined thoroughly through economic analysis.

There had always been constant struggle to overcome the frequently evolved and endemic food problems in Nigeria (Ayanwale and Abiola, 2007). There had been national calls from time to time, to bridge the gap in shortfalls of various ingredients locally. However, cabbage had zero production in the state and all its supplies are related with foreign aspects. Without import of cabbage to Ekiti state consumption would be considered to be zero. Although garden egg, especially the white coloured variety, is being produced in all the sixteen local government areas, and vastly cultivated and made readily available everywhere in Ekiti State,. Cabbage is used as a side dish in salad preparation, whereas garden egg is mostly not taken as the main meal but considered to be a supplementary food. Why is there the mad rush for cabbage importation, if garden egg could be as nutritious and delicious as cabbage intake? Is it possible to replace cabbage with garden egg or whether garden egg would be acceptable to consumers in salad preparation? Now the main question arises towards the real costs and nutritional implications of replacing cabbage with garden egg?

The study is an attempt to provide answers to the above mentioned research questions as how to solve the endemic problems of food insufficiency. It will help the policy makers and provide immense benefits to Ekiti State in general and the Federal Government in particular, to evolve suitable and feasible resolutions to stem out the problems of excessive food importation in Nigeria.

As mentioned earlier, the main objective of the study is to carry out economic analysis of replacing foreign cabbage with local salad ingredients within its research areas. The specific objectives include the following aspects: (i) determination of the possibility of replacing foreign salad with locally sourced salad; (ii) to determine and compare the sensory evaluation of the two categories of salads, so as to determine the degree of acceptability, (iii) estimate cost benefit analysis of the local salad; and (iv) compare and contrast the nutritional values of both the categories of salads with the possibility of curbing and ultimately stopping cabbage importation and, subsequently encourage massive local garden egg fruit production in the state.

The risk factors in preparation of vegetable salad with garden egg fruit and cabbage is at par, apparently same and equal, because both are uncooked. However, the risk factor in cabbage may be higher due to some possible contamination during transportation from foreign countries. The risk of microbial infection is found in all raw and uncooked salad ingredients as reported by NBS (2017). Salads containing raw vegetables have been identified as diarrhea, an illness sometimes experienced by visitors coming into developing countries, in vehicles of travellers. Another microbial flora of partially processed vegetables has also been found in pre-packed mixed vegetable salads, leading towards great concern of both aspects in food spoilage and safety are involved. Even the considerate presence or absence, as well as the fate of both human pathogens and plant tissues spoilage organisms are important factors for some watchful examination (Uzeh et al., 2009). 


\section{MATERIAL AND METHODS}

\subsection{Area of study}

Ado is the capital of Ekiti State and the State is divided into sixteen local area council as indicated in the figure below. Ekiti standard Food outlets are Mr. Bigg, Tantalizer, Fork and Finger, Smiln, Danke, Portofino, Village Port among others. These outlets are not present in other local government areas because they are rural except Ado Ekiti.

\subsection{Data collection}

Primary and secondary data were used to accomplish the objectives of the study. Primary data were collected using detail questionnaire and focused group discussion and laboratory analysis. Deliberately the garden egg was single homogenous recipe type while the one sold in outlets were multi ingredients recipe but the lion share is generally made of cabbage leaf and the foreign salad can be tagged cabbage salad. The desire is to replace the cabbage $100 \%$ by garden egg as single recipe salad or used garden egg as substitute for cabbage in salad preparation in the state. A beautiful white colour type of garden egg is used to replace the white cabbage. Cabbage and garden egg is a multi-colour kind of vegetable.

\subsection{Type of garden egg and imported cabbage}

The type of garden egg considered in this study is the variety that are eaten without cooking with fresh sweet taste white colour though there are several varieties with different colours which are eaten raw. Also, the variety of cabbage considered is the type that can be eaten raw without cooking. In Nigeria there many garden eggs that are eaten raw without cooking. This study does not consider eggplant fruits that require cooking before consumption. Since the two can be eaten without cooking they are substitute for each other but garden egg fruits has been ignored or underutilized in Nigeria.

\subsection{Sampling and data analysis}

A multi stage sampling techniques was used to select respondents. A purposive sampling was used to select Ado out of all the towns and villages in the State. All other towns and villages were rural and standard outlets were not present except Ado. Therefore, Ado was selected because it vividly reflects the feature under study. It was followed by random sampling of five outlets operating in Ado Ekiti. Twenty salad consumers were randomly selected out of the buyers patronizing the outlet. Each twenty were people of different age to accommodate variation in that might arose from age difference of both male and female respondents with a total sample size of 100 respondents in the study area. Descriptive and inferential statistics were applied to data collected. Orthodox budgeting techniques was used to determine the feasibility of changing from foreign salad to local salad while rank correlation was used to determine the correlation between cabbage and garden egg salad. Respondents were allowed to taste and make their decision on a scale of five which form the basis of judgments.

\section{RESULT AND DISCUSSION}

\subsection{Sensory evaluation of local and foreign salad in the study area}

\subsubsection{Colour preference evaluation}

The foreign salad had a better acceptability in terms of colour evaluation. The two had a positive colour and acceptability status of greater than $90 \%$ and negative colour evaluation of less than $10 \%$ (Table 1). The local had a $1 \%$ higher value of negative index and a $1 \%$ lower value of positive colour value indicating a marginal difference in general acceptability among respondents in the state. The outcome indicates that the colour of local salad compete favourably with foreign salad and policy should be geared toward replacing foreign salad with domestic or indigenous source salad in the study area as a way of reducing possible trade deficit in the country in with too much 
dependency on food importation. Therefore, garden egg as domestic vegetable can play a vital role in domestic vegetable food consumption which is in agreement with Abdulai et al. (2018) who indicated that Vegetables play an important role in the household economy and occupy a unique position in both domestic and foreign food trade.

Table 1: Colour preference evaluation

\begin{tabular}{|c|c|c|}
\hline \multirow{2}{*}{ Evaluation Class } & \multicolumn{2}{|c|}{ Frequency } \\
\hline & Local Salad & Foreign Salad \\
\hline Very Poor & 1.00 & 4.00 \\
\hline Poor & 7.00 & 2.00 \\
\hline Good & 31.00 & 22.00 \\
\hline Very Good & 35.00 & 39.00 \\
\hline Excellent & 26.00 & 33.00 \\
\hline Total & 100.00 & 100.00 \\
\hline
\end{tabular}

Source: Field Study, 2018

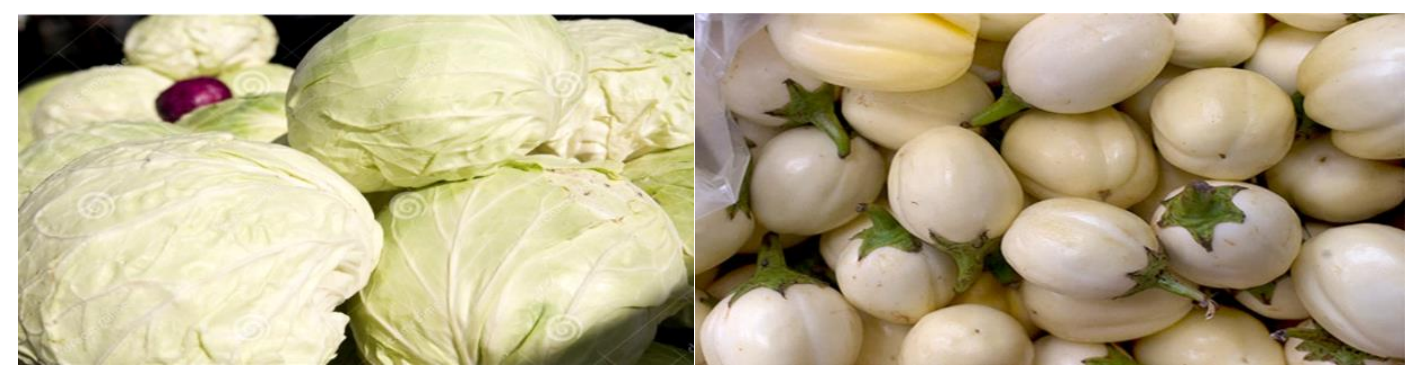

Figure 1: Colour of cabbage and garden egg fruit

Source: Adedayo et al. (2010)

\subsubsection{Odour preference evaluation}

The outcome indicate that foreign salad had a value for very poor but none rated the local salad poor (Table 2). Also, local salad was rated $16 \%$ higher in terms of good attribute value but foreign salad had lower negative scale value. Local salad had total positive scale value of $87 \%$ while foreign salad had a value of $93 \%$. The two had acceptable positive value in odour evaluation indicating the two-smell fresh and good. Therefore, phasing out foreign salad will be with little or no negative impact owning to the good degree of indigenous source salad acceptability and a ready substitute for cabbage. The result demonstrate that garden egg salad made from local source compared favourably with foreign type. Availability is key in food security which is in agreement with (Rusliyadi et al., 2019) who indicates that availability, accessibility are factors in food security and since garden egg is produced locally showcases the replacement of foreign salad with local source enhances Nigeria food security. The domestic economic will be better off because of lesser import bills and associate cost.

Table 2: Odour preference evaluation

\begin{tabular}{|c|c|c|}
\hline \multirow{2}{*}{ Odour Class } & \multicolumn{2}{|c|}{ Frequency } \\
\hline & Local Salad & Foreign Salad \\
\hline Very Poor & 0.00 & 1.00 \\
\hline Poor & 13.00 & 6.00 \\
\hline Good & 43.00 & 27.00 \\
\hline Very Good & 25.00 & 41.00 \\
\hline Excellent & 19.00 & 25.00 \\
\hline Total & 100.00 & 100.00 \\
\hline
\end{tabular}

Source: Field Data, 2018 


\subsubsection{Matching evaluation by teeth}

Foreign salad had better teeth grinding evaluation status than local salad. This is probably due to lower moisture availability in garden egg which makes it harder to chew than cabbage with higher water content making it softer in term of texture and grinding capacity of teeth. However, there are varieties of garden egg with higher moisture capacity that can neutralize these negative features and harvesting early will also count in term of improving mouth grinding status of local salad.

Table 3: Matching preference evaluation

\begin{tabular}{|c|c|c|}
\hline \multirow{2}{*}{ Marching Class } & \multicolumn{2}{|c|}{ Frequency } \\
\hline & Local & Foreign \\
\hline Very Poor & 70 & 2 \\
\hline Poor & 7 & 11 \\
\hline Good & 4 & 20 \\
\hline Very Good & 2 & 29 \\
\hline Excellent & 17 & 29 \\
\hline Total & 100 & 100 \\
\hline
\end{tabular}

Source: Field Data, 2018

\subsubsection{Taste preference evaluation}

The local garden egg salad is perfect substitute for cabbage salad (Table 4). The two had equal negative and positive evaluation status in the study areas. The study outcome indicates that Nigerians has good acceptability status for their products provided there is availability. In most cases in Nigeria some food item has no local substitute: for instance, Igbemo rice is popular rice in Ekiti State but such rice does not appear in standard shops because of poor packaging since there is no bag, label or brand for this local rice but it is sweeter and generally available in the state. The rice is sold in Gerri cans, Kongo, paint rubbers and other local measures. The taste of this rice is generally more acceptable to consumer. In most standard outlets cooked Igbemon rice attracts a unit price of five hundred naira while the foreign rice attracts two hundred and fifty naira. The outcome here indicate that Nigeria can come out of food importation problem if it can work more on domestic source and other neglected food resources in the country.

Table 4: Taste preference evaluation

\begin{tabular}{lcc}
\hline Evaluation Class & Local Salad & Frequency \\
\hline Very Poor & 1.00 & Foreign Salad \\
Poor & 6.00 & 2.00 \\
Good & 32.00 & 5.00 \\
Very Good & 38.00 & 31.00 \\
Excellent & 23.00 & 25.00 \\
Total & 100.00 & 37.00 \\
\hline
\end{tabular}

Source: Field Data, 2018

\subsubsection{Orthodox budgeting analysis evaluation of garden egg and cabbage salad}

The orthodox budget analysis indicates that there is 216.5-naira positive beneficial revenue gained per $\mathrm{kg}$ for producing garden egg salad instead of cabbage salad (salad Table 5). The outcome shows that garden egg salad is more profitable than cabbage salad in the study areas. Ten units are derivable in every kilogram of garden egg fruit or cabbage. A salad unit is sold at standard price of \#300 in food outlets operating in Ado Ekiti. Garden egg fresh fruit commands an average price of \#97.5 per kilogram while cabbage fresh leaf was sold at a mean value of \#314 per kilogram. Cabbage is more expensive because it is not produced at all in the state. It is $100 \%$ foreign in the state. Cabbage contains more water and transportation and other factors probably accounts for high 
price. Garden egg contains lesser water but it is produced in all the 16 LGA areas in the state. It is 200 times cheaper. Garden egg in all season has lower price than cabbage. However, the market price of cabbage and garden egg salad is the same making the sales of garden egg salad more profitable ceteris paribus. A ban on importation of cabbage will have a serious positive effect on garden egg production and demand in the state. The outcome indicates that replacing cabbage with garden egg is feasible. The production of garden egg salad attracts lower transaction and production which can lead to rapid business expansion because lower transaction cost will attract higher demand for loan which is in agreement with (Ali, 2019) who hypothesized that, high transaction costs resulted in less demand for loans. The production of garden egg salad is expected to have lower cost because of inverse relationship between demand and price.

Table 5: Orthodox budgeting analysis of garden egg and cabbage salad in the study areas

\begin{tabular}{lcc}
\hline Price $(\mathbf{K g} / \mathbf{N})$ & Cabbage & Garden egg \\
\hline Market price & 3000.0 & 3000 \\
On season & 200.0 & 70 \\
Of season & 428.0 & 125 \\
Average price & 314.0 & 97.5 \\
Orthodox Budget Analysis & & \\
Revenue gained for producing Garden Egg Salad & 3324.0 & \\
Cost incurred for not producing Cabbage Salad & 3097.5 & \\
Decision Deferential & 216.5 & \\
\hline
\end{tabular}

Source: Field Data, 2018

\subsubsection{Correlation analysis between garden and cabbage salad sensory evaluation}

The outcome of correlation analysis between the two salads indicates a perfect linear correlation between garden egg salad and cabbage salad. The two are usually side dishes consumed with main meal such as fried rice and jollof rice to provide minerals and vitamins mostly available in inadequate form in the main meal. The correlation indicates the two are perfect substitute for each other. The correlation value of 1 is also significantly different from zero indicating that the two salad types had positive association.

\subsubsection{Chemical and nutritional composition of garden egg and cabbage}

The outcome indicated that Garden egg fruit and cabbage in terms of moisture content mineral and chemical composition were good substitute as indicated in table below. Garden has higher protein content and good vitamin E content which is absent in cabbage. Cabbage has higher iron content but generally garden egg has higher essential nutrient value than cabbage. The nutritional content of both vegetables is presented below.

Table 6: Chemical and nutritional composition of garden egg and cabbage

\begin{tabular}{lcc}
\hline Parameters Concentration (\% Dw)* & Garden Egg Fruit & Cabbage \\
\hline Moisture & $91.4 \pm 0.56$ & $92.18 \mathrm{~g}$ \\
Ash & $21.2 \pm 0.42$, & \\
Crude Lipid & $12.5 \pm 0.07$ & $0.1 \mathrm{~g}$ \\
Crude Protein & $8.31 \pm 0.63$ & 1.28 \\
Crude Fibre & $6.22 \pm 0.36$ & 1.5 \\
Available Carbohydrate & $51.74 \pm 0.32$ & $5.8 \mathrm{~g}$ \\
Estimated Caloric Value & $308.9 \mathrm{Kcal}$ & $25 \mathrm{~kg}$ \\
Mineral Element (Mg/100g DW) & & \\
Phosphorus & 1085.00 & 26 \\
Magnesium & 39.14 & 12 \\
Potassium & 216.89 & 170 \\
\hline
\end{tabular}




\begin{tabular}{lcc}
\hline Manganese & 147.0 & 0.18 \\
Copper & 256.17 & 0.019 \\
Sodium & 149.34 & 18 \\
Iron & 326.50 & 0.47 \\
Calcium & 15.29 & 40 \\
$\mathrm{Ca} / \mathrm{P}$ & 0.01 & \\
$\mathrm{~K} / \mathrm{Na}$ & 1.45 & \\
Vitamin Concentration (Mg/100g DW) & & \\
Riboflavin (Vitamin B2) & 0.036 & 0.234 \\
Ascorbic Acid (Vitamin C) & 6.273 & 36.6 \\
A-Tocopherol (Vitamin E) & 0.140 & 00 \\
\hline
\end{tabular}

Richard and Ali (2011)

\section{CONCLUSION}

It has been established in this study as a factual result that cabbage salad had to be replaced with garden egg fruit salad which has the capacity to reduce import dependence on foreign food (cabbage) with adequate abilities to build self-sufficiency on, and also encourage domestic food production in Ekiti State in Nigeria.

The correlation result indicates that the imported cabbage and garden egg fruit are perfect substitute mutually for each other. The correlation value of 1 is also significantly different from zero indicating that the two salad types have positive association. Garden egg fruit salad could be compared favorably with foreign cabbage salad in terms of colour, taste and general acceptability among consumers, across various age groups in the study areas.

Based on the outcome of the study, it is recommended that Nigeria will be at an advantage if the importation of cabbage from Benin Republic, Cameroon and other countries could be banned to encourage domestic production of salad ingredients in Ekiti State.

Funding: This study received no specific financial support.

Competing Interests: The authors declared that they have no conflict of interests.

Contributors/Acknowledgement: Authors wish to appreciate Mr. and Mrs. Ibidapo the parent of Adebayo Clement who provide the full fund for this undergraduate project.

Views and opinions expressed in this study are the views and opinions of the authors, Asian Journal of Agriculture and Rural Development shall not be responsible or answerable for any loss, damage or liability etc. caused in relation to/arising out of the use of the content.

\section{Reference}

Abdulai, A., Fior, S. C., Andivi, B. J. E., \& Jumpah, E. T. (2018). Technical and resource use efficiency of urban vegetable farming in the Kumasi Metropolis: A stochastic frontier approach. Asian Journal of Agriculture and Rural Development, 8(2), 92-108.

Adedayo, B. C., Oboh, G., \& Akindahusi, A. A. (2010). Changes in the total phenol content and antioxidant properties of pepper fruit (Dementia tripetala) with ripening. African Journal of Food Science, 4(6), 403-409.

Afolami, C. A., Obayelu, A. E., Agbonlahor, M. U., \& Lawal-Adebowale, O. A. (2012). Socioeconomic analysis of rice farmers and effects of group formation on rice production in ekiti and ogun states, south-west Nigeria. Journal of Agricultural Science, 4(4), 233-244. doi.org/10.5539/jas.v4n4p233.

Ali, I., \& Richard, A. (2011). Nutritional and chemical evaluation of solanum. Journal of Tropical Medicine and Public Health, 1(1), 96-107. 
Ali, R. (2019). Credit demand among small farmers: a district level approach, Pakistan. Asian Journal of Agriculture and Rural Development, 9(1), 47-61.

Audu, O. (2018). Annual food import and export analysis. Nigeria https://www.vanguardngr.com/2018/08/nigeria-spends-22bn-annually-on-food-importationaudu-ogbe/

Ayanwale, A. B., \& Abiola, M. O. (2007). Efficiency of fluted pumpkin production under tropical condition. Journal of Vegetable Science, 13(3), 35-49.

CBN (2010). Central bank of Nigeria annual report bulleting. Nigeria. https://www.cbn.gov.ng/OUT/2011/publications/statistics/2010/index.

Lakin, T. (2018). An evaluation of Nigeria food import bill. Abuja Nigeria. https://shipsandports.com.ng/evaluation-nigerias-food-import.

NBS (2010). Nigeria bureau of statistic. Annual Review Bulleting Abuja, Nigeria https://nigerianstat.gov.ng/elibrary.

NBS (2017). Nigeria bureau of statistic. Annual Review Bulleting Abuja, Nigeria. https://nigerianstat.gov.ng/.

Nigerian Government (2018). Nigeria import value of sugar wheat rice and fish. Vanguard, Nigeria.

Nwaogu, L. A., Alisi, C. S., \& Ibegulem, C. O. (2007). Evaluation of $\beta$ - carotene content and presence of some Phytochemical in Five indigenous Fruits. Plant products Research Journal, 10, 13-15.

Oboh, G., \& Elusiyan, C. A. (2004). Nutrient composition and antimicrobial properties of sorrel drinks (soborodo). J. Med. Food, 7, 340-342.

Oboh, G., Puntel, R. L., \& Rocha, J. B. T. (2007). Hot pepper (Capsicum anum, Tiepin and Capsicum Chinese, Habanero) prevents fe2+ indicated lipid peroxidation in Brain: In vitro. Food Chem., 102, 178-185.

Ogiehor, I. S., Nwafor, D. E., \& Owheureghe, U. B. (2008). Changes in the quality of Zobo beverage produced from Hibiscus sabdariffa in Roselle and the effects of Extractsm of ginger alone or in combination with refrigeration. Afr. J. Biotechnology, 7, 1176-1180.

Rusliyadi, M., Hj. Mohd, J. A. B., \& Kumalasari, R. T. (2019). Analysis of household food security policy: case of food security village programme, Indonesia. Asian Journal of Agriculture and Rural Development, 9(1), 19-32.

Uzeh, R. E., Alade, F. A., \& Bankole, M. (2009). The microbial quality of pre-packed mixed vegetable salad in some retail outlets in Lagos. Nigeria Journal of Food Science, 3(9), 270272. http://www.academicjournals.org/AJFS. 